\title{
Táctica Lírica de Carlos Augusto Salaverry.
}

\section{LINEAS FN SU VIDA.}

Este año de I94I, cuyo lento deslizarse sobre la superficie del tiempo, se realiza en medio de una atmósfera densa de contenido bélico, ha registrado para el Perú, una fecha muy significativa en el campo literario. Para recordarla, tendríamos que trasladarnos a París - cincuenta años atrás- a un nueve de-Abril de I89ı. Allí, alejado de su tierra natal, moría uno de nuestros más altos románticos, el poeta-soldado Carlos Augusto Salayerry. Una acesante y prolongada lucha contra el mal, ponía epílogo a su vida extrañamente interesante, en donde todo había conspirado, para ayudarlo a lograr una perfecta misión lírica en el mundo.

Cuando Felipe Santiago Salaverry viajó a Piura en I830, se enamoró de doña Vicenta Ramírez: el cuatro de Diciembre del mismo año, nacía el futuro poeta: "Hijo natural" anota la Partida de Bautismo, asentada en uno de los libros de la Parroquia de San Miguel de Piura, por el presbítero Miguel de la Cruz León. Fueron sus padrinos don Pablo Seminario y doña Paula Godos, quedando así ligado, el recién nacido, por lazos terrígenos y espirituales, a los soleados arenales norteños.

Esta su condición de "hijo natural" debió tener una 
honda repercusión en su vida. $Y$ aunque el padre, atrabilario pero caballeroso, no se la hizo notar jamás, el poeta sintió muy dentro su dolorosa intimidad, que después iba aflorar en la irónica amargura de muchos de sus versos.

E1 muchacho apasionado, hijo de un brillante caudi1lo, se dejó deslumbrar rápidamente por el prestigio afortunado de los uniformes de gala. Joven aún, lo vemos inclinarse hacia la carrera del padre, e iniciar y proseguir con éxito sus primeros movimientos. Pero tenía en sí el destino de cantar. No podía haber pugna, para un romántico, entre la carrera militar y el culto por las musas, sino, por el contrario se complementaban magníficamente en el agitado programa de su vida. Así los primeros versos de Salaverry surgieron naturalmente, entre los silencios de unas veladas, vistiendo él, uniforme de oficial, y teniendo como confidente de poesía a uno de sus jefes.

Teobaldo Elías Corpancho nos ha hecho llegar una anécdota, a través de las acuciosas páginas de un ensayo de Alberto Ureta: "A fines de 1855 , una noche, Carlos Augusto Salaverry volvía ail cuaptel de Santa Całalifia, donde se en-

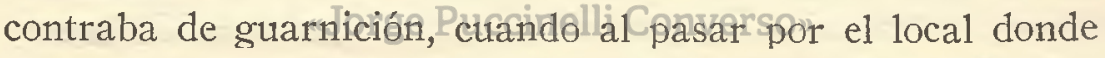
entonces funcionaba el Consejo de Estado en el Portal de Escribanos, y que hoy ocupa la Municipalidad de Lima, encontró en la puerta de esa casa al militar y poeta don Trinidad Fernández, a quien tocaba ese día mandar la guardia en el referido local. Salaverry, hace entonces, al poeta amigo una confidencia: había escrito una composición poética. La sorpresa de Fernández fué inmensa cuando terminó la lectura, no solo porque encontró buenos los versos, sino porque sabía que Salaverry, hasta entonces, era ajeno por completo a todo trato con las musas". (I)

(1) Alberto Ureta._"Carlos Augusto Salaverry".-Lima 1918. 
La vida del poeta proseguía, alternando la pluma con la espada, grata emulación que conciliaba en él, los arrebatos bizarros de la imaginación con la vitalidad en suspenso de sus nervios En tanto, una fantasía impaciente y una pasión desbordante lo impulsaban hacia los escenarios. Sentía la atracción de los aplausos ríspidos y el encanto de la ovación coronando los diálogos como un penacho de gloria. Siguiendo la ley de todos los románticos escribió para el teatro con entusiasmo y fecundidad.

Ricardo Palma, inveterado socarrón, lo hace notar en "La bohemia de mi Tiempo" (2). Y Marcelino Menéndez y Pelayo, después de hacer juegos de palabras con los títulos de sus poemarios, añade: "Dió culto también a las musas del teatro, pero ninguno de sus dramas, incluso Atahualpa, que es el más conocido, ha tenido gran éxito" (3). En lo del éxito, el crítico español, ignoraba que los dramas románticos de Salaverry y sus compañeros, gozaban de un triunfo caluroso aunque efímero, arrancado por la sonoridad transitoria y un poco ajena, de sus versos grandilocuentes.

El poeta gustabateciertatructilencia en los títulos de sus obras teatralesgゆespués de 'Arturo (advocación breve, pero abierta en insinuaciones....) vino "Abel o el pecador americano"; luego "Atahualpa", estrenado cuando el poeta frisaba los 28 años; en seguida "Los Ladrones de Alto Rango", "E1 Amor y el oro", "Sueños del Corazón”, "El Hombre del Siglo XX", "El Virrey y la Favorita", "El Bello Ideal", "Gigantes y Pigmeos", "El Pueblo y el Tirano", y una traducción de Moliere "La Escuela de las Mujeres". Fué una esforzada labor, mantenida con tenacidad y constancia y que, sin embargo, estuvo condenada a ese destino de limbo o de in-

(2) Ricardo Palma.-_"La Bohemia de mi tiempo".-Lima 1899.

(3) Marcelino Menéndez y Pelayo.- "Antología de Poetas Hispano-Americanos"'--Madrid 1894. 
fierno alegre, a donde la remitía, con risueña mataperrada el propio Ricardo Palma, apologista y denostador de sus compañeros de bohemia.

Pero es condición esencial a los románticos, la infelicidad sentimental. Salaverry conoció este duro designio del corazón en dos ocasiones en que, con extraña coincidencia, un mismo final doloroso puso epílogo a sus aventuras. Ese primer amor definitivo que aparece en la vida de los poetas, fué para Salaverry, el de Ismena Torres: "Era una mujer sencilla que se ignoraba a sí misma" escribe en una carta dirigida a Luis B. Cisneros (4). El poeta la quería por su encantadora ingenuidad, por su absoluta ignorancia del valor de la poesía: "Ella se reía hasta las lágrimas con la lectura de mis dramas" confiesa. Pero la familia desconfía de la seriedad de este cantor de versos y envía a la novia a Europa "para que olvide". Idilio trunco por un matrimonio de conveniencia, que Salaverry glosó en un intensionado soneto:

"Los dos te amamos con ardor constante....."

Una crisis sentimentahlel limpuserla necesidad de viajar, y un incidente en que su vida se vió comprometida, le aproximó aun más, a la oportunidad. E1 presidente José Balta simpatiza con el poeta y lo envía como adjunto a la Legación del Perú en Francia, en la misión encomendada a Pedro Gálvez, otorgándole, además, una subvención que facilitara la publicación de sus versos. Es así como llega a París en Febrero de i87o, en época en que Luis B. Cisneros se encontraba de cónsul en el Havre. A sus cuidados entrega la publicación de su obra, mientras Salaverry marcha a conocer la Ciudad Eterna. A su regreso de Roma,

(4) Carlos Augusto Salaverry.- "Albores y Destellos" -Le Havre 1871. 
escribirá en Londres el 28 de Julio de I871, la dedicatoria de "Albores y Destellos" al coronel don José Balta.

Todavía el poeta pisaba tierras extranjeras cuando en I876 Ricardo Palma le encomienda la edición de "Verbos y Gerundios", que se imprinió en Francia precedida de unas breves frases liminares de Salaverry. Dos años después se encontraba de regrese en Lima. No obstante, el mismo oscuro destino lo perseguía. Un nuevo amor, y de nuevo, la oposición de la familia de la novia, provocan la terrible separación por el mar. Corría el año I882, y el poeta no puede soportar tan insistente desgracia. Al año siguiente viaja, también él, a París, y luego de contraer matrimonio, hace un recorrido por el viejo continente, como un baño lustral que borre el dolor de tantos contratiempos. Sin embargo, ya no se encuentra joven, y algún tiempo después, le sobreviene la parálisis. Combatiendo contra ella y en plena lucidez mental, pasa sus últimos días. Es un atento y desgarrado observador de esta pugna de la naturaleza con la muerte, y de esta manera, en su puesto de lucha, militar y poeta, muere después de haber cantadco $\mathrm{q}_{a}$ vida en amplios y musicales versos.

\section{LECTURA POETICA.}

En "Albores y Destellos", publicado en el Havre en I87I, Carlos Augusto Salaverry reúne la totalidad de su obra lírica. Tres libros sucesivos: "Diamantes y Perlas", "Albores y Destellos" y "Cartas a un Angel" integraban las diferentes posiciones sentimentales de su sensibilidad estética. Como auténtico romántico, Salaverry registraba las variaciones de su vida en la emotiva taquigrafía de sus versos. La estrecha interdependencia que existió entre una y 
otros, explica varios de los elementos fundamentales de su poesía.

No se equivoca Ureta al afirmar que el poeta "ve en el dolór una ley fundamental en la vida". La perseverancia de una torva y permanente angustia da el gran matiz a su obra, en la que se reconocen influencias de Espronceda, Leopardi, Vigny y hasta de Numa Pompilio Llona, según hace notar su comentador. Sin embargo, estas son tan indiscutibles en nuestros románticos, que nos hemos acostumbrado a mirarlas sin escándalo y con saludable naturalidad.

En cambio, Salaverry no es monótono como hubiera podido acaecer, y tiene la superioridad de su discreción líri$c a$, frente a los desbordes sentimentales de sus compañeros. Ventura García Calderón 10 considera "nuestro más sincero y apasionado poeta" (5), y da a la palabra apasionado el valor de un dignísimo elogio.

Aunque en "Albores y Destellos", con alguna frecuencia, Salaverry se deja contagiar por el entusiasmo propio de su clima poético, siempre se encuentra refrenado por un tono de modestia, que imprime la elegancia de su línea a varios de los poemas, como aquél que dedica a Felipe Pardo y Aliaga, en señal de admiración:

"La humilde flor que el delicado broche abre bajo el rocío de la noche

$\mathrm{y}$ en las tinieblas sus aromas vierte, seméjase a mi musa desolada

cantando las grandezas de la nada

y el resplandor sombrío de la muerte....."

La idea de la muerte lo obsesiona como a todos los románticos. La siente en su lejanía cercana, pero dentro de

(5) Ventura Gareía Calderón.- "Del Romanticismo al Modernismo". 
una placidez que viste de un raro color su angustia. Por eso su expresión no es violenta, sino de paradójica conformidad:
"Goza como las aves una aurora
Vive como la flor, una mañana
Nube que el sol con sus reflejos dora,
Leve rocío que del cielo mana. . . . .
¿Por qué infeliz, tu corazón devora
la idea de otro mundo que te afana?
Mientras la luz del sol aun reverbere
Nace, alégrate, goza, llora, muere!!!"

La estructura de su sentimiento está sujeta a grandes entusiasmos y a grandes depresiones. Por eso dice, en otro de sus versos, que "esperar es vivir"; para, a continuación, seguir jugando con la idea de la vida, cono un leit-motiz, predilecto a su espíritu. Bruscos cambios, lo reintegran rápidamente a "su realidad". Su realidad de poeta, diferente de la de los demás hombres, que fe gititąen lo más hondo: "Jorge Puccinelli Converso»

"En vano se iluminan mis cabellos

de la niñez con el dorado sol, la tristeza del alma puso en ellos

la temprana ceniza del dolor....."

versos que son una lejana raíz de otros de Alberto Ureta, en el Dolor Pensativo, cuando expresa:

"Se quema el tiempo sin cesar. Las horas cáen hechas ceniza, y ruedan al abismo de la nada las dicha y las penas confundidas."." 
En "Diamantes y Perlas" su ámbito es diferente. Salaverry se place en manejar el soneto, con la alegría de la gimnasia de una técnica nueva:

"Tengo como Colón un nuevo mundo de seres que mi espíritu ha soñado..."

El esfuerzo de vencer las dificultades de la forma, le comunica cierta euforia. Habla de la vida como de una copa perfumada en su soneto "Inmortalidad"; y al recordar a Manuel Nicolás Corpancho, muerto trágicamente en alta mar, tiene frases gallardas:

"Futeron de llamas y salobre espuma

Los pliegues de tu sábana mortuoria.

Pero en la mar no se abismó tu historia,

Ni tu cantar se disipó en la bruma...."

En esta época de su vida, Salaverry no se siente abatido por el destino, sino lo enfrenta esgrimiendo frases 1lenas de ironía. Aspira $Q$ escudarse tras tina broma bulliciosa, para ocultar "sareamargura, pero no fo"consigue enteramente, percibiéndose la esperanza trágica de una desdicha profundamente desgarrada. Aunque sin traicionar a su grupo, predomina en él la nota subjetiva e íntima, muy distante del colorido patriótico que caracteriza a Luis B. Cisneros, por ejemplo; o del sentido de versatilidad intelectual de Juan de Arona, traductor de los clásicos y, al mismo tiempo, letrillista incorregible.

Su carrera poética llega a su estancia más alta en las páginas de "Cartas a un Angel", precedidas de un prólogo epistolar autobiográfico. Declara que son "cartas de amor", y más adelante advierte que "carecen de fantasía, de literatura y de fecundidad". Con ello quiere expresar la 
transparente sencillez que anima muchas de sus canciones:
"Ni soy artista alma mía
$\mathrm{Ni}$ ser científico anhelo,
Mas siento que la armonía
La hizo Dios antes que el día
Para el idioma del cielo". (6)

Puesto que son para un ángel las cartas, uno de los temas predilectos del libro es el cielo. Para llegar a él, trata de libertarse de los ataderos de las preocupaciones terrenales:

"De verme alegre te admiras

Sin dinero y sin cuidados;

Pero envidiosa me miras

Tú, jilguero que suspiras

Por entre alambres dorados....."

$Y$ se acercảcon facilidad finísima a la entraña del nadrigal, dulce en șufluidez, iyealadonenrsus imágenes:

“¿Dónde tu aroma de inocencia rara

Red invisible, vaporosa y leve

$Y$ el pudor que al de un ángel se compara

$Y$ aquel seno que un Fidias envidiara

Tallado en mármol, alabastro y nieve?.."

Esto ya es el proceso del sutilizamiento de la idea romántica, que despojándose de toda retórica ornamental y sin abandonar la brillantez de sus metáforas, ingresa a un salvador sendero de equilibrio:

(6) "Albores y Destellos", El Yaravi. 
"Dios dijo al ave de los bosques: canta.

Al tierno cáliz de la flor: perfuma.

A la estrella: las nubes abrillanta.

Al sol: irradia en Ia azulada bruma.

Al ambiente: suspira. Al río: encanta

Con tus bellezas de argentada espuma.

$\mathrm{Y}$ a tí mujer para el amor nacida

"Te ha dicho acaso Dios: ¿Ama y olvida?"

Simplicidad lírica, recato en las imágenes, discreción formal podrían estimarse como las cualidades de la poesía de Salaverry. Y alguno se preguntará: ¿̇son estos valores para consagrar una poesía?. La respuesta en este caso, tendría que ser categórica. La apreciación de estas virtudes no puede realizarse en abstracto, Pero cuando se considera que en el desborde romántico, el primer valor que naufragó fué la discreción, tenemos que reconocer unánimemente en Salaverry -y en su discreción lírica-la más pura voz de nuestro movimiento romántico.

\section{Lima, 1941. Biblioteca de Letras "Jorge Puccinelli Converso"}

LUIS Fabio Xammar. 